\title{
Martial Guéroult, crítico da crítica hegeliana* \\ Observações sobre o lugar da exegese em filosofia
}

\author{
Sílvio Rosa Filho**
}

Resumo: Trata-se de mostrar em que sentido é possível falar de limitações da leitura estrutural aplicada à filosofia hegeliana, especificamente quando esta elabora a crítica da moralidade de Kant. A partir da análise empreendida por um artigo de M. Guéroult acerca do tema, fazse uma comparação entre os princípios por ela assumidos sobretudo na dianoemática, isto de um lado, e, de outro, as exigências teóricas e práticas que, propriamente hegelianas, presidem o desdobramento da crítica.

Palavras-chave: crítica - sistema - moralidade - deslocamentos - método e doutrina estruturais

"Im ernsten Beinhaus wars, wo ich beschaute
Wie Schädel Schädeln angeordnet passten”
(Goethe, "Bei Betrachtung von Schillers Schädel”)***

Durante toda a sua vida Hegel elaborou, como se sabe, uma crítica da filosofia prática kantiana ${ }^{1}$. Teria sido antes de tudo uma interpretação deformadora e sistematicamente viciosa? Uma fabulação imposta, todavia, por conceitos? Tal é, autoconduzido a seu próprio extremo, o resultado expresso da interpretação proposta por M. Guéroult² ${ }^{2}$ e parece que, para além do lugar-comum em

* Este texto é a primeira parte de um estudo acerca do comentário gueroultiano da crítica hegeliana.

** Doutorando do Departamento de Filosofia da Universidade de São Paulo e bolsista CNPq. *** "No severo ossuário foi que eu vi/ Caveiras a caveiras ordenadas” (“Ao contemplar o crânio de Schiller”. In: Poemas. Trad. P. Quintela. Coimbra, Centelha, 1986). 
que se encerra e faz questão de repetir, ele vem entabulado numa posição digamos: controversa e talvez fecunda - concernente à relação entre os procedimentos da crítica e a elaboração do sistema.

Para o professor do Collège de France, encarregado da cadeira Histoire et technologie des systèmes philosophiques, Hegel aparece como dotado de um estatuto, decerto, excepcional: no filósofo alemão, reconhece o próprio “pai fundador da história moderna da filosofia”, que, no entanto, vítima de sua própria genialidade, acaba por se revelar, graças a essa crítica da crítica, como um de seus mais sistemáticos falsificadores. Nestes termos, porém, na relação entre filosofia e história, o desenrolar da obra hegeliana propriamente dita, na medida em que neste desenrolar a crítica de Kant desempenha um papel internamente constitutivo, não exprimiria mais que o momento de atualização de uma falsidade... Já se pode antever que, se a crítica "estrutural” da crítica hegeliana estivesse apta a nos preservar de toda sorte de equívocos (datáveis: geneticistas, evolucionistas, historicistas etc. $)^{3}$, ainda assim poderia muito bem ser ao preço de um conjunto de pressupostos de não menor gravidade, apto, por seu turno, a fazer descarrilhar objeções e contra-objeções de igual equivocidade: por exemplo, Hegel não seria satisfatoriamente um dianoématicien, assim como Guéroult não seria satisfatoriamente $o$ filósofo. Mas, por um lado, nunca será demais insistir, a crítica hegeliana requer de seu leitor o cultivo de uma paciência bastante peculiar e, por outro, a crítica de sua crítica permitiria entrever, no limite, o que não fazer: assim, se o caminho do espírito é mesmo o do desvio, seria recomendável desenvolver mais demoradamente os problemas envolvidos no estudo da moralidade; e, afinal, quem foi minimamente educado pela escola francesa de história da filosofia aprende entre outras coisas que, quando um comentador como Guéroult parte convictamente para o ataque frontal a um filósofo, incide no que se poderia designar como reducionismo e deixa referências importantes reservadas ao campo do silêncio, é muito provável que tais atitudes não se dêem por obra de mero acaso. Daí valer a pena, antes de abordar em pormenor o artigo citado, uma tentativa de apresentar algumas das principais tendências teóricas que norteiam a crítica da crítica, como também repor, em tempo devido, o problema do lugar a partir do qual a exegese da crítica hegeliana, por sua vez, faz sentido. 
A meta do estudo em questão é estabelecer a natureza e o valor da crítica hegeliana. Para tanto, Guéroult segue um percurso bem diverso daquele adotado em suas grandes monografias, mas ainda assim recorrente ${ }^{4}$, e que por sua simplicidade poderia ser caracterizado como uma démarche classique: sempre a primeira parte comporta uma exposição analítica, ao passo que a segunda leva a efeito uma crítica, ou, se quisermos, uma pars destruens. Trata-se então, num primeiro momento, de recolocar a crítica hegeliana em seu contexto primitivo, visando apreender a significação que ela assume para o próprio hegelianismo. Em seguida, trata-se de levar a cabo uma confrontação dessa crítica com os textos kantianos e fichtianos, assumindo previamente a finalidade de determinar que a doutrina moral professada por Kant e por Fichte, tida por ambos como definitiva e suficiente, seria independente do "processo dialético" onde, de acordo com Hegel, ela tem seu lugar e sua verdadeira significação (Guéroult 7, p. 62) . $^{5}$

À primeira vista esse propósito, deliberadamente polêmico, faria eco a inúmeras "refutações", tão cândidas quanto ideológicas, com as quais o pesquisador do assunto estaria habituado a lidar. Refletindo sobre a idéia de estrutura na exegese filosófica, V. Goldschmidt observou certa vez que, em nossa época, "não constituíram objeto de uma reflexão fundamental as condições de possibilidade, no sentido transcendental da expressão, de uma história que parece dominar sobre os sistemas como elementos seus, para ordená-los e coordená-los numa consciência que só poderia ser a de Deus (é na compreensão dessa exigência que se enraíza a doutrina hegeliana do Espírito Absoluto - doutrina profunda e incômoda, que a ideologia do momento não cessa de perseguir com suas cândidas refutações)" (Goldschmidt 6, p. 258). Se o estudo gueroultiano dos deslocamentos não é propriamente um exemplar de pura inocência, longe disso, tampouco se podem atribuir a ele as facilidades habituais de uma "refutação ideológica”. Pelo contrário, como sucintamente gostaríamos de mostrar, tudo indica que esta licença polêmica do historiador depende de seu próprio ancoramento programático, em que se manifesta uma espécie de solidariedade entre o historiógrafo minucioso e o dianoemático em projeto, o polemista convicto e o monógrafo rigoroso. Mas em que medida esta parceria do especialista consigo mesmo, delineando o esboço de uma imbricação complementar, compromete a recontextualização gueroultiana da crítica de Hegel? Será que, em sua forte inclinação para apreciar aquilo que o kantismo "autenticamente ensi- 
nou”, a urgência polêmica não incorre, por exemplo, no incômodo problema da exterioridade?

Tais questões têm sua razão de ser, pois, como lembra Rubens Rodrigues Torres Filho, “o caráter próprio da filosofia de Hegel, discurso que devora seus pressupostos, é tal, que a alternativa do comentador em face dela parece irrecusável: ou criticá-la em nome de critérios externos, caindo em descrédito diante de um oponente que de antemão dá conta dessa exterioridade, ou compreendê-la internamente, mas de tal modo, que, por um efeito das leis internas do discurso, qualquer tomada de posição se torna problemática, pelo menos no nível do discurso hermenêutico, sem mudança de registro” (Torres 28, p. 141). Seria melhor dizer então que Guéroult fica a meio caminho entre tais alternativas: de uma parte, não reconhece o teor essencial do ancoramento hegeliano no registro lógico-dialético e especulativo, o que o obrigaria a se encaminhar por "desvios” que o gênero polêmico simplesmente não comporta e, por conseguinte, abandonar o registro da Realität, feito sob medida para as filosofias do entendimento; de outra parte, não acompanha o andamento crucial da forma da realidade efetiva (Wirklichkeit), o que até certo ponto seria fazer jus ao itinerário in mentis auctoris ${ }^{6}$, sem deixar de explicitar, por isso mesmo, as condições em que uma mudança de registro demandaria toda uma rearticulação do próprio conceito de filosofia. Ocorre que, por vias transversas relativamente ao trilho conceitual hegeliano, Guéroult produz um remanejamento do conceito de filosofia - à sua maneira, é claro. "Definida como 'filosofia das filosofias', a Dianoemática só poderia ser concebida por um historiador”, constata Goldschmidt, para logo acrescentar, "mais precisamente: por um historiador que praticasse a 'tecnologia dos sistemas', ou seja, 'a análise das técnicas constitutivas’ de cada sistema” (Goldschmidt 5, p. 233) 7 .

Logo, se é lícito falar em limitações gueroultianas, isto se deve ao fato de que, por um lado, elas estarão destinadas a garantir não somente o caráter de "positividade" - ou seja: a instituição - da dianoemática. Entendida por seu autor como uma disciplina transcendental - dianoema (doutrina) dedicada à investigação das condições de possibilidade das filosofias como objetos de uma história possível -, sem dúvida "salta aos olhos a inspiração kantiana desse projeto" (id., ibid., p. 236). Por outro lado, tais limitações operam um recuo da disciplina transcendental perante uma tarefa que não pode, nem deveria, ser a sua; assim circunscrita por si mesma, foge de sua alçada dar conta de filósofos 
que todavia não foram “autores”, tais como Sócrates, os mestres da Nova Academia, Ammonios Saccas, Epíteto e Plotino (Goldschmidt 5, p.236). Por este lado também é possível entender a seguinte sentença, referida ao patamar que, não obstante situado no registro fenomenológico, deveria conferir legitimidade ao discurso hegeliano: a empresa crítica, afirma Guéroult, "é válida na medida em que Hegel pretende refutar a doutrina enquanto historiador” (Guéroult 7, p. 63). Mas com isto a crítica hegeliana das proposições descentradas da Visão Moral do Mundo não é reconhecida como legítima, a não ser na medida em que Guéroult peca por excesso e por escassez, por excesso, generaliza o texto fenomenológico dos deslocamentos como se a crítica fosse já toda a crítica da doutrina professada por Kant; por escassez: concede ao fenomenólogo do espírito uma roupagem de historiador na qual o porte filosófico de Hegel, de todo, não se ajusta. Ainda por este lado Guéroult arromba, por assim dizer, uma porta aberta ao criticar a deformação da Moralität, ao passo que o texto hegeliano se punha a operar, justamente, a crítica dessa deformação enquanto Weltanschauung. Em suma, as proposições deformadas por essa Verstellung em que descai a Moralidade aparecem então como situadas - em seu conjunto, embora não insulado - numa Visão Moral do Mundo, e é precisamente nesta segunda que a consciência fenomenológica faz a experiência singular do teor ilusório - porém necessário - da primeira.

A parte analítica do estudo gueroultiano procura atender à preocupação de dar resposta à seguinte pergunta: em que nível se põe, para Hegel, o problema da filosofia prática kantiana? Segundo momento do desenvolvimento do espírito objetivo, terceira e suprema etapa da Moralität -, a reconstituição devolveria a seu terreno primitivo um lugar circunscrito no âmbito arquitetônico, pois Guéroult sugere articulações entre a Enciclopédia das ciências filosóficas e as Linhas fundamentais da filosofia do direito, antes de retornar à passagem da Fenomenologia do espírito que forneceu o primeiro título de seu artigo. Se para Guéroult a cronologia das obras não se confunde com o itinerário filosófico do autor, como é de uso, a exposição prometeria repor a Moralidade na economia do sistema. 
Trata-se, entretanto, de uma preceptiva metodológica fácil de postular e difícil de cumprir, sobretudo quando lavrada nos limites do gênero polêmico, além de um complicador suplementar, técnico mas não menos importante: a vigência da prescrição concerne a uma obra que, antes de receber o subtítulo de "sistema da ciência: primeira parte", trazia nos manuscritos a inscrição deste outro: "arquitetônica do saber fenomênico". O que acarreta pelo menos duas conseqüências. A primeira, retrospectivamente, reside no fato de o polemista desconsiderar os momentos fenomenologicamente anteriores à Moralidade, quais sejam, a dialética do Iluminismo e sua culminância na Revolução Francesa. É curioso que, no capítulo sobre o propósito (Vorsatz) e a culpa (Schuld), nas Linhas fundamentais da filosofia do direito, enquanto seu autor cita dois exemplos (Hegel 18, §§ 115-118), a recontextualização gueroultiana alude apenas ao primeiro (Guéroult 7, p. 50): para ilustrar uma espécie de descompasso entre a vontade virtualmente culpada e o mundo externo e distinguir entre homicídio (involuntário) e assassinato (voluntário), Hegel compara um exemplo da antiguidade a outro da época moderna. Por uma parte, único exemplo aludido por Guéroult, a consciência de si heróica encarnada no Édipo que, se vivesse em nossos dias, teria direito a "circunstâncias atenuantes", pois o parricida não sabia que era Laio o seu pai no caminho de Tebas. Por outra parte, a inteligência formal, posta diante de um acontecimento complexo como a Revolução Francesa, dispõe da possibilidade de escolha entre uma multidão de circunstâncias pelas quais poderá ou não imputar a responsabilidade do acontecimento à vontade; neste segundo exemplo, todos os agentes históricos trouxeram a sua contribuição (os reis com sua política, os intelectuais com sua propaganda, o povo com sua revolta), e a dificuldade ou a limitação, pelo menos para o "entendimento" que tenciona meditar sobre a história de modo moralizante, é poder reconhecer o verdadeiro sujeito em questão. Ainda retrospectivamente, a crítica hegeliana dos deslocamentos implica movimentos regressivos para a consciência, um dos quais é assinalado pelo próprio texto. Em primeiro lugar, enquanto pertinente ao momento determinado do espírito certo de si, a Visão Moral do Mundo parecia chegar a uma espécie de apaziguamento que é perturbado pela natureza (em si, para si, ou mesmo divina), caindo numa multiplicidade de relações morais, “do mesmo modo que um objeto da percepção em geral é uma coisa com múltiplas propriedades” (Hegel 15, p. 117), o que convida o leitor a revisitar o segundo capítulo da obra, à luz de suas correlações estruturais com a 
criteriologia moral. Em segundo lugar, enquanto momento particular do espírito em oposição à certeza e à verdade da razão como razão legisladora, esta etapa nos remete por seu turno ao momento do capítulo da certeza e verdade da razão, que, por sinal, sucede às ponderações de Hegel sobre o "reino animal do espírito e a impostura, ou a Coisa mesma”. Estruturas fenomenológicas comparáveis, visto que, embora distintas, ambas se manifestam como sintomas de regressão.

A segunda conseqüência tem um alcance prospectivo em relação à crítica hegeliana dos "deslocamentos". Uma vez desarmados, esse "ninho inteiro de contradições" (Hegel 15, p. 110) vem demandar que o pensamento hegeliano alce novos vôos, dos quais a Fenomenologia do espírito é seguramente a primeira expressão. Por um lado, como momento que prepara a consciência para o advento do saber hegeliano propriamente dito, na interconexão entre o Espírito e a Lógica, impõe-se uma releitura do Prefácio da Fenomenologia, lugar privilegiado para uma apreensão das urgências teóricas em nome das quais se opera a crítica hegeliana: é certo que, neste registro especulativo, não deveríamos nos contentar com o emprego de Wirklichkeit como se Hegel estivesse admitindo tacitamente alguma individualidade pressuposta (Napoleão, o próprio Hegel), ou como se o emprego desta categoria estivesse caucionando uma intuição qualquer, uma representação da coletividade humana, que permitiria o acesso ao objeto ou àquilo que assumisse a responsabilidade existencial pela síntese das determinações do Conceito. Por outro lado, se a moralidade implementa uma escansão peculiar do negativo, tal negação é a negação de um outro; ora, se esse campo ainda não chegou ao seu direito (idem 19, § 257), compreende-se que, já na filosofia do direito, o problema será apontar para as lições "positivas” que Hegel entende extrair da elucidação dos equívocos nos quais incorrera a Visão Moral do Mundo; mantendo com esta uma relação entre-expressiva, a moralidade subjetiva prepara a possibilidade de uma eticidade, não mais adstrita ao mundo grego, mas inserida em contextos sociais propriamente modernos, a Sittlichkeit. Nesta esfera da moralidade, tem lugar a gênese subjetiva da universalidade abstrata que mantém relações conceitualmente determinadas com a história narrativa (die Historie) de um indivíduo que se cultiva. A subjetividade se inscreve, por certo, no desdobramento do espírito objetivo e pode encaminhar-se para a filosofia da história, trazer consigo as orientações rumo à história da filosofia e ao reconhecimento do primado da lógica; nem por isso os textos 
deixam de levar em consideração dinâmicas específicas de uma vivência marcada por conseqüências políticas não menos consideráveis, como é o caso dos movimentos regressivos contidos na lógica interna do moralismo subjetivo (cf. Hegel $18, \S 140)$.

Compreende-se que Guéroult se contente com uma caracterização geral, mas dela salta aos olhos do leitor uma omissão considerável: nem na enumeração de suas fontes, nem no decorrer de todo o artigo, em nenhum momento Guéroult se refere explicitamente ao texto da lógica hegeliana, instância da qual a Fenomenologia do espírito de 1807 constitui, precisamente, a introdução. A este respeito, o comentador insiste em sugerir somente um "mecanismo" que, apriorístico, limita-se a deslocar os conceitos kantianos de sua esfera primitiva - a exigência teórica da razão prática que reflete sobre o prático -, para fazê-los deslizar no próprio fato prático como essência absoluta da Moralidade.

Para empregar o léxico da filosofia kantiana, o projeto da dianoemática consiste na tentativa de descrever a Idéia de uma disciplina. É no interior dessa filosofia crítica da história da filosofia que será possível recontextualizar os princípios que organizam a partilha dos papéis assumidos pelo filósofo da história da filosofia. Quando Guéroult reitera sua própria crença de que o ponto de partida do historiador não é outro senão a admissão de que a história da filosofia existe de fato, quando fixa este fato sob o enfoque da possibilidade de uma história da filosofia objetivamente válida, é porque, segundo ele, "sempre se pode concluir ab actu ad posse" (Guéroult 8, p. 41-2). O sentimento que anima e apura os historiadores da escola objetiva, entre os quais ele próprio se inclui, é portanto aquele de que carecem os céticos, isto é, o sentimento da realidade filosófica dos sistemas. Não há dúvida de que tal crença difere da experiência religiosa, que, endereçada ao coração, não participa da experiência reclamada por Guéroult, a que se dirige à razão filosofante (id., ibid., p. 50). Partindo deste pressuposto, Hegel é removido para a região um tanto insondável dos sentimentos, mas à sombra dos quais, graças à intervenção do dianoemático, consegue-se fazer a partilha entre aquilo que o filósofo de fato fez e aquilo que deve- 
ria ter feito: é que, lamenta Guéroult, ele traz une philosophie toute faite para justificar seu sentimento de realidade histórica, quando deveria partir desse sentimento para descobrir, peu à peu, condições que o tornariam válido ou não (Guéroult 8, p. 27). É evidente que, sob tais parâmetros, só se obtém que a perspectiva de que cada filosofia (supondo que filosofia seja perspectiva) vá se envolver num redemoinho onde as alternâncias de ponto de vista não procedem senão de escolhas arbitrárias. E no entanto, como reconhece Guéroult, o recurso ao sentimento não passaria no fundo de uma maneira de oferecer, aos nãoiniciados, uma justificação para o interesse que a história da filosofia é capaz de despertar (id., ibid., p. 53).

Somos então convidados a percorrer um itinerário através do qual a resposta afirmativa à questão quid facti - antes de ser conciliada com a resposta à questão quid juris ${ }^{8}$ - permite promover o interesse do historiador em detrimento daqueles interesses que, comprometendo o valor objetivo das doutrinas, vão tecendo o avesso do estruturalista gueroultiano: configurado num quarteto (diletantismo, pedagogismo, cientificismo e psicologismo epistemológico), seus elementos alinhavam as recusas do dianoemático. Aqueles nos quais predomina o interesse pelo jogo brilhante de idéias, prazer intelectual que acompanha o dilentantismo combinatório (eventualmente mais e mais complexo, desenvolvido e criptográfico), deixam escapar a natureza mesma do interesse filosófico: esta, é claro, "não reside na complicação combinatória que eles [os objetos dignos da história] propõem, pois, a este respeito, certos sistemas de astrologia esquecidos levariam a melhor sobre as maiores doutrinas filosóficas" (id., ibid., p. 55). Por sua vez, o interesse pedagógico contribui para o robustecimento e formação do “espírito filosófico", talvez tornando-o apto à resolução de problemas postos no presente, porém, padece de parcialidade na propensão a reduzir inteiramente o interesse filosófico a esses dois componentes, deslizando "na direção de postulados contestáveis” (id., ibid., p. 57). Já o interesse cientificista, inseparável do processo de especialização, acabou contribuindo para isolar (e com isto identificar) o "núcleo metafísico" das doutrinas em sua irredutível especificidade; todavia, reduz a filosofia a mero instrumento para uma solução cientificamente definitiva, sem poder dar conta do não-paralelismo estrito entre filosofia e ciência. Por fim o psicologismo epistemológico empreende, em relação às filosofias passadas, uma espécie de sintomatologia à luz normativa do 
progresso das ciências positivas, como se houvesse, entre estas e aquelas, a escansão de ritmos idênticos (Guéroult 8, p. 59).

Evitados esses reducionismos do interesse histórico, outras precauções se mostram imprescindíveis. Nesta busca de evitar fundamentalmente o apriorismo, uma espécie de preambula fidei se impõe, já que a resposta à questão de direito envolve a resposta à questão de fato: com efeito, "é do maior interesse, para ajudar a definir com precisão e assentar solidamente a nova crítica, descrever previamente a constituição do fato histórico da história da filosofia e seguir, através do tempo, o movimento paralelo da livre reflexão filosófica sobre esta história” (idem 9, p. 2). Esta providência historiográfica não se quer reduzida a uma simples doxografia, mas antes considera as filosofias enquanto sua diversidade e divergência constituem, para elas mesmas, um problema. Resulta que essa historiografia gueroultiana do problema difere de uma rapsódia errática e deve permitir, em princípio, articular a primeira como história crítica da história da filosofia à dianoemática como filosofia crítica da história da filosofia. Partindo da antiguidade clássica e chegando aos modernos, não há como evitar o caráter seletivo do procedimento historiográfico: assim, por exemplo, "é evidente que não seria possível nem passar inteiramente sob silêncio a patrística e a escolástica nem, tampouco, segui-las no conjunto de seu desenvolvimento histórico. Só serão consideradas no limite em que permitiram promover certas formas duráveis da história da filosofia, em que puseram o problema dos direitos da tradição filosófica diante da filosofia espontânea, em que pressentiram a necessidade de uma posição do valor filosófico da tradução como condição de sua conservação sob o título de objeto digno da história possível" (id., ibid., p. 5; o grifo é nosso). Ou seja, na medida em que, por antecipação, encontra-se insinuada, nos meandros do passado, a possibilidade de uma história objetiva da filosofia, e por conseguinte a possibilidade da própria Idéia como dianoemática, Idéia daquelas idéias como objetos de uma historiografia necessária. É sob este mesmo enfoque que o historiógrafo, minucioso na seleção de um pressentimento da dianoemática, não poderá deixar de se haver com o "pai fundador da história moderna da filosofia”. Hegel, dirá Guéroult, "ao determinar filosoficamente $a$ priori a lei da história, o sistema determina a priori o conteúdo desta. Ao extrair de cada sistema a Idéia que lhe é subjacente, da totalidade de cada um deles a Idéia daquelas Idéias, ou seja, a totalidade absoluta daquelas totalidades parciais e provisórias, o conceito de 
desenvolvimento arruína a suficiência e a autonomia de cada doutrina. Só se basta e se mostra autônoma a razão de todo o desenvolvimento" (Guéroult 12, p. 185) $)^{9}$. Malgrado todas as afirmações do próprio Hegel no sentido de considerar a filosofia kantiana como ponto de partida (Ausgangspunkt) da filosofia moderna alemã (cf., por ex., Hegel 17, p. 45), não é de Kant que se poderia tratar; somente um Kant exponencialmente hegelianizado poderia fecundar o pensamento hegeliano (Guéroult 11, p. 133). Como a afirmação vem deslocada enquanto mera alegação, remete-se a um "kantismo real”, que, conservado intacto pela chancela do historiador, nenhuma ação direta poderia exercer sobre a idéia agora hegeliana do kantismo. Distância e isolamento recíprocos podem ser levados ao máximo quando a filosofia de Hegel, en possession de toutes ses vues, acredita descobrir sua própria essência e fundar sua realidade na razão viva (cf. id., ibid., p. 126); nenhuma oposição direta, portanto. Mas será que, se entendermos essas "alegações” hegelianas em função dos interesses do historiador na conservação do kantismo, poderemos também entender por que, precisamente, Hegel se apropria do kantismo? Teria sido em nome de um kantismo real que Hegel trata de circunscrever, nas Linhas fundamentais da filosofia do direito, um campo para a reabilitação das filosofias do entendimento contra, por exemplo, a função pretensamente legitimadora de fatores tais como o bom coração, a boa intenção e a convicção? (Hegel 18, § 140, ad.).

Admitamos que, ao deplorar o "mecanismo" como procedimento generalizado, Guéroult estivesse nos autorizando uma remissão a outros capítulos da Fenomenologia como o da "razão observadora", onde, ao precisar o sentido do universal-de-razão, Hegel acoplava, justamente a este primeiro, o universal no sentido do conceito, ou seja, uma apresentação para a consciência como o presente e o realmente efetivo. Nos termos postos para essa figura singular concreta, "o que é universalmente válido, também vigora universalmente. O que deve ser, também é, de fato. O que apenas deve ser, sem ser, não tem validade alguma” (idem 14, p. 164). Sucede que, não mais no âmbito da certeza e da verdade da razão, o ponto principal (der Hauptpunkt) não é o que somente é de fato e segundo o decreto da razão que observa a natureza, mas passa por uma inflexão inapreensível no âmbito da facticidade, para não falar no nível de uma empiricidade mais chã. É que não há um campo de indiscernibilidade total entre estratagemas para manipular o ser e o vir-a-ser do ser que se pensa ao vira-ser. O essencial não é se deixar convencer de que aquilo que deve ser também 
seja na platitude de um fato, mas antes reconhecer que a Fenomenologia, dirigindo-se para a constituição do ponto de vista moral, apresenta os momentos de aprendizado de uma figura singular concreta como itinerário formador para a compreensão especulativa da completude (Vollständigkeit). Claro, se o acompanhamento desse trajeto conduz a pôr em evidência que, de acordo com Hegel, a filosofia transcendental padece de incompletude, os tratamentos por ele conferidos à filosofia prática kantiana conduzem a impasses de tal ordem, que será possível compreender por que ela permanecerá condenada a não realizar efetivamente a filosofia. Hegel procede de tal modo, que - reconhecendo que Kant percebera a contradição (interna, necessária e essencial) das antinomias, mas ainda assim permaneceu circunscrito a uma certa negatividade (apenas abstrata) concernente ao resultado dessa contradição; enfim, elevando-se, a partir da negação de um conteúdo determinado, até o novo conteúdo afirmativo resultante dessa negação - sua própria arquitetônica faz com que a figura fenomenológica da Visão Moral do Mundo se torne a consciência que a Moralidade subjetiva tem de si mesma. É neste campo da completude sistêmica que, sem apartar os fatos de sua significação na rede da realidade efetiva, a problemática hegeliana do Sollen se coloca e pode se mostrar como dotada de sentido.

Sob a égide da razão pura prática, distinta de uma razão meramente observadora, enquanto proveniente do mundo efetivo (a vida ética do povo grego), assim como do reino da fé e da intelecção (o também chamado período das Luzes e por fim o da liberdade absoluta sob o terror autodestrutivo da Revolução Francesa), a Moralidade "entra em uma outra terra do espírito consciente de si onde a liberdade absoluta, nessa não-efetividade, assume o valor do verdadeiro” (Hegel 15, p. 100). Poderíamos então perguntar: não haveria portanto, para Hegel, um modo de ser nessa inefetividade do dever-ser, assim que este passa a assumir, partindo da liberdade absoluta, nada menos que o valor do verdadeiro? Mas se estivesse reduzindo a lógica hegeliana a mero mecanismo a priori - para assim salvaguardar a essência absoluta da moralidade como exigência teórica da razão pura prática, exigência que reflete e não opera um deslizamento sobre o fato prático -, Guéroult não estaria em completo desacordo com Hegel. Por certo, tal reconhecimento não depende do fato enquanto idealidade do imediato e do natural; e tudo levaria a pensar que alguém pudesse se dizer hegeliano, mesmo colecionando reservas quanto ao modo pelo qual o professor Hegel redigiu empiricamente anotações de aula para sua história da 
filosofia. O que se entende por recurso ao fato, portanto, longe de significar uma resolução, um ponto pacífico para se evitar apriorismos, constitui, justamente, um problema, sobremaneira quando o fato é - como algo obtido e conquistado, essencialmente mediatizado - o "fato" da filosofia.

Voltando à dianoemática, o fato em questão - aquele destinado a garantir a não-incorrência em idéias pré-concebidas - ganha tanta amplitude quanto for necessário para a assunção, mediante contraste não absoluto ou glissement, de um dado, só que entendido agora como o conjunto da história da filosofia, o que significaria, pois, desde logo, a possibilidade de passagem à questão de direito. Se procedermos com mais vagar com relação a essa sensibilidade realísticoobjetiva, veremos que, salvo menoscabo, perante a envergadura das objeções hegelianas, não é tão fácil como parece o recurso ao fato e sua subseqüente transposição no dado, para não falarmos ainda da passagem à questão de direito. Na introdução à Fenomenologia do espírito, após fornecer uma amostra inicial de que a crítica do conhecimento supõe por sua vez uma crítica dessa crítica, e assim ao infinito, o filósofo afirma que, no que concerne ao emprego de termos como objetivo e subjetivo (poderíamos acrescentar: o fato e o dado), "dando a entender, de um lado, que sua significação é universalmente conhecida, e, de outro, que se possui até mesmo o seu conceito, parece antes um esquivar-se à tarefa principal que é a de fornecer esse conceito” (Hegel 14, p. 65). Ora, o bem-conhecido em geral, justamente por ser bem-conhecido, não é objeto de reconhecimento. "É o modo mais habitual de enganar-se e de enganar os outros: pressupor no conhecimento algo como já conhecido e deixá-lo tal como está. Um saber desses, como todo vaivém de palavras, não sai do lugar - sem saber o que lhe sucede. Deus, natureza, o entendimento, a sensibilidade etc. são sem exame postos no fundamento, como algo bem-conhecido e válido, constituindo pontos fixos tanto para a partida quanto para o retorno" (id., ibid., p. 37). Se Guéroult se detivesse com mais vagar nestas considerações, não lhe seria difícil atentar, ademais, para uma passagem em que Hegel problematiza a maneira de designar o momento do completo ser-outro: “Assim como a expressão da unidade do sujeito e do objeto, do finito e do infinito, do saber e do pensamento etc. tem o inconveniente de significar que o sujeito, o objeto etc. são fora de sua unidade, e, portanto, na unidade não são o que sua expressão enuncia, do mesmo modo o falso é um momento da verdade, [mas] não mais como falso" (id., ibid., p. 42). A breve e oportuna nota de J. Hyppolite esclarece, por 
remissão a um texto de juventude, o fato de que Hegel, em plena consciência, reconhece os opostos como não sendo a mesma coisa fora de sua síntese e dentro de sua síntese: “Os opostos são, antes da síntese, algo de inteiramente outro após a síntese; antes desta, são opostos e nada mais, um é o que o outro não é, e o outro o que aquele não é mais” ${ }^{10}$. Longe de desconhecer que caiba ao historiógrafo uma tarefa empírica, ao mesmo tempo, aqui será preciso lembrar que o filósofo não se reconhece inteiramente nesta tarefa ${ }^{11}$.

$\mathrm{O}$ que estava em jogo no trajeto gueroultiano do fato ao dado era a passagem do problema do valor objetivo das doutrinas àquele de seu valor de verdade. Visto que, como se sabe, cada doutrina pretende ter "formalmente" atingido este valor como adaequatio maxima rei et intellectus, cada uma delas arruína as demais, desqualificando-as como falsas, a despeito do fato de estas também pretenderem o mesmo valor. "A afirmação dessa verdade é $a$ priori a afirmação de um certo valor” (Guéroult 8, p. 60). Aqui, precisamente, ao reconhecer a necessidade de tratar desse problema do valor, em nota marginal Guéroult hesitava entre duas alternativas: deve ser a verdade concebida como engendrada pelo valor propriamente dito, ou deve ser a verdade, tal como será definida por cada filosofia, concebida como engendrando o valor? Este segundo elemento da disjuntiva, no corpo do texto, fica relegado a segundo plano para retornar com toda a sua força por outro viés, já que, por ora, o historiador se encaminha no sentido de admitir a primeira, isto é, que "fundar e determinar este valor é fundar a realidade dos sistemas filosóficos presentes na história, e com isto, justificar mediatamente o interesse da história da filosofia como tal” (id., ibid.). Por via de conseqüência, não é difícil presumir que quanto mais o historiógrafo confirmar e reforçar seu próprio sentimento de realismo objetivo, não apenas se pode esperar que se apresente com as credenciais da imparcialidade e da neutralidade, como também tanto mais convicto tenderá a se mostrar o polemista. Assim a verdade - alocada antes de tudo como valor - permitirá falar em uma pretensão formal, algo assim como uma ossatura, entroncando cada filosofia; por intermédio deste procedimento de locomoção à primazia axiológica, fica aberto um campo ao perspectivismo do historiador e uma outra necessidade se impõe, a de empreender aquilo que se poderia batizar com o nome de uma "crítica das antinomias do juízo (reflexionante) do gosto (ou do senso) filosófico" 12 . 
Em contrapartida, se o historiador se demorasse na segunda parte da disjuntiva, seria difícil elidir a complexa problemática de saber se, efetivamente, cada filosofia dá conta de sua pretensão à máxima adequação entre a coisa mesma e o seu conceito. Ora, decerto a dianoemática opera a distinção entre, por um lado, a vérité de jugement (visada como tal por todo sistema), e por outro, a veritas in re (única atingida, mas de modo apenas intrínseco). Vale notar que o historiador, na medida em que faz a "experiência" dos diversos sistemas, devidamente desguarnecidos de suas respectivas pretensões de verdade, não tem como se furtar a uma certa passagem do projeto transcendental a um gênero de ligação, ainda que pela negativa, com uma ontologia de intuitos não dogmáticos - quer dizer, os diversos juízos de verdade remetem ao problema da verdadeira realidade destas pretensões discordantes como problema que, ineludível, requer solução. A exigência desta questão da "vraie réalité” (Guéroult 10, p. 68) é tal, que caberá ao dianoemático cumprir uma tarefa que, oferecendo sua acolhida à miríade de discordâncias em que os filósofos recaem, vem intimálos a um tribunal de última instância, instaurado para levar a termo duas metas fundamentais: pela arbitragem das discórdias que entre as filosofias se apresentam, o dianoemático desempenha o papel de juiz supremo; pela pronúncia de um non liquet argumentado, ele passa a polemizar contra o caráter obscuro ou não convincente de um litígio. Tudo portanto se encaminhava para que, desde a adoção de um ponto de vista empírico, capacitado para conferir ao projeto dianoemático sua verdadeira originalidade, atingíssemos este patamar diferencial onde se edifica o tribunal da razão gueroultiana, fonte da qual deverá promanar a verdadeira realidade. O que não se dará sem a colocação de problemas, muitos, alguns dos quais não se podem negligenciar.

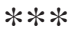

O próprio dianoemático se encarrega de formular alguns deles, já no limite do procedimento analógico entre as filosofias e as obras de arte. A partir de um certo ponto em que não mais se tratar do gozo estético ou do Belo, mas do conhecimento e da Verdade, a atitude de considerar as proposições relativas ao mesmo problema como meras expressões diferenciadas de uma mesma verdade, ou da verdade mesma, será uma atitude vedada ao dianoemático. 
Esse interdito é fundamentalmente uma decorrência de duas condições. A primeira é a "missão" que a si mesma cada filosofia se dá, cabendo ao historiador explicitar monograficamente, segundo a ordem das razões, o papel, a definição e as pretensões de cada filosofia: como sabemos, a atitude de pôr em evidência a arquitetônica de uma obra filosófica, mostrar a profunda coerência de seu pensamento, é uma atitude solidária daquela de nunca se entregar à empresa de criticar Descartes ou Espinosa, por exemplo, mas antes dar acesso ao sentido mesmo da doutrina estudada. "Se há um pressuposto no método estruturalista - e é o único, e o que caracteriza a sua total isenção -, é que o filósofo é considerado responsável pela totalidade de sua doutrina, assumida como tal por ele, e que é, portanto, na sua compreensão dela, explicitada ou implícita nela, que se deve buscar a inteligência de suas asserções” (Porchat 26, p. 10). Na primeira aula do Curso de Estética de 1966, Bento Prado Jr. ${ }^{13}$, tematizando a pretensão de neutralidade diante das escolhas filosóficas, observou que, por sob o pressuposto mínimo de responsabilidade total, ela não deixa de ter seus próprios pressupostos ou escolhas de teor essencialmente metafísico. Será aqui suficiente reter o primeiro deles, segundo o qual é possível dizer tudo: com efeito, se dizer algo (para nós: alocar uma proposição) é calar outra coisa (alteridade deslocada, proposição que desloca a primeira), então, para o estruturalista, o silêncio é apenas provisório, quer dizer não significativo. Sabemos ao contrário que, para Hegel, este silêncio é fenomenologicamente significativo, desde os primeiros passos do itinerário em que a certeza vai se pondo à prova para a reconquista reflexiva de sua verdade como razão, e sobretudo quando se tratar da Visão Moral do Mundo, já que, vale lembrar, uma das muitas maneiras de traduzir a Verstellung é vertê-la como simulatio ${ }^{14}$. Atendo-se à crítica de Guéroult-monógrafo, Bento Prado dizia: “O Descartes de Guéroult corresponde exatamente às Meditações de Descartes; trata-se, no fundo, do mesmo livro, mas tal como seria escrito por um Descartes que fosse integralmente Descartes. Não se trata, propriamente, de um livro 'sobre’ Descartes, mas de um livro que retoma a palavra cartesiana, pondo em evidência todos os elos da longa cadeia de razões que até então haviam permanecido na sombra. Descartes é um Guéroult parcial e Guéroult é um Descartes liberto de suas limitações; seu livro preenche todas as lacunas deixadas em branco pelo livro de Descartes”15. Nessa intensificação dos pormenores argumentativos, outra coisa está em jogo: a passagem de um plano a outro, da linguagem à metalin- 
guagem. Poderíamos acrescentar: da filosofia auto-suficiente à metafilosofia que lhe é sobreposta e suplementar.

Projetados num mesmo plano, na sobreposição que vai recobrindo a explicação e o explicado, o texto é encarado em uma espécie de isolamento narcísico, dirá também Bento Prado - cujo caráter se mostra, afinal, como ahistórico. Visto que a história para Hegel não está em relação de conformidade exclusiva com a história da filosofia, a crítica da crítica hegeliana não reconhece sua envergadura, a não ser passando por ela de um modo demasiado rápido, ao promover sua dissolução imediata numa fórmula, tanto mais abstrata quanto meramente ritual, o Esprit universel. Ao fazer economia de mediações significativas, tal dissolução, no que respeita à Moralidade, é problemática em pelo menos três aspectos. Em primeiro lugar, a crítica da crítica não repõe os problemas históricos presentes na interconexão sistêmica hegeliana. Já na década de 80, para citarmos um autor insuspeito, A. Stanguenec, adepto confesso do estruturalismo, concluiu seu Hegel critique de Kant observando que um estudo da relação entre Hegel e o kantismo ainda estaria por ser feito: tal pesquisa deveria explicitar as etapas pelas quais se constrói o "ponto de vista” do idealismo transcendental, não apenas no próprio Kant, mas ainda, através de Fichte e de Schelling, para culminar no sistema hegeliano (Stanguenec 27, p. 333-4) ${ }^{16}$. Em segundo lugar, no âmbito da Fenomenologia do espírito, a crítica da crítica deve silenciar aquele ponto de mira da arquitetônica do saber fenomênico concernente à necessidade de uma formação integral do homem moderno, na medida em que Hegel, operando uma descrição dos fenômenos da consciência, vincula dois processos fundamentais e simultâneos, homólogos embora não exatamente isomorfos: com efeito, o processo de autoconhecimento da consciência (que vai da certeza sensível até a idade da razão) é indissociável do processo histórico-social da humanidade (que parte do estágio da servidão e se endereça à realização da liberdade); se as configurações (Gestalten) podem aparecer como realidades historicamente objetivas é porque cada qual, como um estado do mundo (Weltzustand), responde a desafios postos pela situação do homem na história mundial, não apenas alocados na esfera onde a história é de pronto a história da filosofia (Marcuse 22, p. 99). Pois a filosofia hegeliana se apresenta como fornecendo respostas tanto aos desafios provenientes da Revolução Francesa quanto àqueles herdados de Kant e que poderiam ser aqui condensados na seguinte abreviatura: o homem, que não é livre, deve ser livre, se quiser ser 
homem. Em terceiro lugar, no que concerne estritamente à caracterização do capítulo sobre a Moralidade, caso se passe imediatamente ao espírito do mundo, está de antemão descartada a mera possibilidade de entender que a crítica da Visão Moral do Mundo - formalismo, inefetividade, contradições internas se apresenta como uma crítica, também ela, relativamente esvaziada de conteúdos histórico-sociais, caso posta em comparação com os capítulos anteriores, nos quais se encontrava toda uma profusão de observações positivas acerca dos conteúdos do Iluminismo francês e antes que ficasse patente a "reconciliação" do terror jacobino com a sociedade que o engendrou e solicitou ${ }^{17}$. Seria uma tal vacuidade (Leerheit) somente indício da evaporação de todo referente operada pelas filosofias do entendimento?

Não há dúvida de que, se Hegel aparecer como o "mal absoluto" do gueroultianismo, se o limite do estruturalismo se encontrar em Hegel, não é como autor de minuciosa monografia que caberá a Guéroult comentá-lo dans les textes; esta tarefa ficará reservada, compreende-se, ao polemista convicto cuja reconstituição se opera a partir de quelques textes. Por sua vez, Hegel não se vê, de fato, como um "comentador” de Kant. Daí que, à luz do que foi dito acima, possamos afirmar que o "Kant” de Hegel não corresponde exatamente à filosofia prática de Kant. Não se trata de repetir ao infinito Kant, redigindo uma autocrítica do kantismo, tal como ela seria escrita por um Kant que fosse integralmente Kant. Trata-se, propriamente, de uma crítica filosófica da filosofia prática de Kant, não de uma explicação que retomasse a palavra kantiana para pôr em evidência todos os elos da longa cadeia de razões que até então haviam permanecido na sombra. O que permanece "na sombra”, graças à intervenção do polemista convicto, é justamente um dos elementos constitutivos do problema mesmo da filosofia prática hegeliana, não porque Kant seja um Hegel parcial e Hegel um Kant emancipado de suas limitações. Neste sentido, não há por que ler a filosofia prática de Hegel como se viesse preencher as lacunas deixadas em branco pelo texto da filosofia prática kantiana. O que Hegel repõe é, de modo sui generis, o problema da realização efetiva de toda filosofia prática. É por isto que ainda pode suscitar algum interesse, que, como interesse pelo universal, se inscreve no âmbito de um interesse que não é apenas o do entendimento, mas da razão.

A segunda condição que leva Guéroult a recusar a "verdadeira realidade" a que pretende Hegel é a “estrutura lógica de nosso espírito”, isto é, as exigên- 
cias mesmas do pensamento verdadeiro segundo o historiador da escola objetiva - Hegel diria: vicissitudes da lógica do entendimento. Explícita ou implicitamente postas por cada filosofia, tais expressões não são apenas diferentes, mas antes, reconhece e assinala Guéroult, contraditórias (Guéroult 8, p. 64). Caberia então a pergunta: afora o contorno do campo estrito da representação, não estariam tais contradições, constátaveis de fato pelo historiador, providas de algum valor objetivo? O dianoemático se limitará a dizer que a resposta à questão quid juris parece dever refutar toda resposta afirmativa à questão quid facti, com o que somos devolvidos à região do sentimento, com um adendo: "Não somente o sentimento do valor intrínseco das doutrinas, o que se impõe a todo representante da história objetiva da filosofia, se choca com a pretensão de cada doutrina à 'verdade exclusiva' (pois, se efetivamente uma filosofia é verdadeira, a pretensão do historiador de que todas elas descobrem um dado objetivo de verdade é insustentável), mas ainda encontra a impossibilidade lógica de conceber seu fundamento possível” (id., ibid.; os grifos são do autor). O que Guéroult recusa em Hegel e compromete sua própria recontextualização é o próprio ponto de partida hegeliano, quer dizer, o reconhecimento e a tentativa de dar conta de que, justamente, as filosofias são contraditórias, por mais que este ponto de partida ${ }^{18}$ seja rejeitado como algo de vulgar, comum - ou algo diverso, popular; ou ainda, por mais que esta barreira se lhe mostre como algo intransponível.

Aparece para nós como algo evidente que, por um lado, a argumentação gueroultiana só pode comparecer como argumento porque já foi suposto, de início, aquilo mesmo que estava em questão: o não-valor de verdade como vérité de jugement é declinado a toda filosofia que não possuir o caráter da dianoemática como lugar onde se decide acerca da legitimidade da vraie réalité. Por outro lado, ao se reconhecer como que impedido, pela estrutura lógica de seu espírito, de dar conta da reconhecida contradição das filosofias, impede-se de pôr em consideração a estrutura lógica - desconcertante em mais de um aspecto - do espírito hegeliano. Para falar com Hegel, à medida que progride a Cultura, a Razão se opõe àquela rigidez em que o entendimento fixa a absoluta cisão (Entzweiung) como relação auto-exclusiva entre a inteligência e a natureza (Hegel 16, p. 6); ou ainda opõe-se à cisão que se pretenda consolidada entre a subjetividade absoluta e a objetividade absoluta: "A cisão é fonte da necessidade da filosofia e, enquanto cultura de uma época, o aspecto desprovido de liberdade, ou o aspecto dado da forma (...) superar tais oposições enrijecidas é o único 
interesse da razão" (Hegel 20, p. 109). Nessa decidida recusa de todo ponto de partida meramente representativo (cf. idem 19, § 451), como um dos momentos mais agudos de que se origina a própria filosofia hegeliana e epílogo reflexivo do desdobramento em seu aspecto fenomenológico, o tratamento conferido à Moralidade encontra um lugar privilegiado. Por seu turno, enquanto momento terminal da Idéia, a questão da contradição não-resolvida (der unaufgelöste Widerspruch) é reposta, e não simplesmente eludida. O feixe de remissões à Moralidade efetuadas pela filosofia do direito, filosofia da história e história da filosofia é indissociável das remissões sugeridas pela ciência da lógica, por mais completa que seja, em si e para si mesma, a exposição fenomenológica, dando testemunho da complexidade do problema envolvido. Com efeito, no que concerne à idéia do bem, "a completa elaboração da contradição não-resolvida, deste fim absoluto à qual faz face, de maneira intransponível, o limite da realidade efetiva, se acha considerada de modo mais preciso na Fenomenologia do espírito" (idem 17, p. 362) ${ }^{19}$. Se nos reportarmos ao entrecho desta passagem, não será difícil verificar que a instância especulativa nos põe perante uma precisão complementar: "A idéia do bem acabado (des vollendeten Guten) é por certo um postulado absoluto, mas não como um postulado, isto é, o absoluto afetado pela determinidade da subjetividade. Há ainda os dois mundos em oposição, um reino da subjetividade nos espaços puros do pensamento transparente, um reino da objetividade no elemento de uma realidade efetiva exteriormente variada, o qual é um reino fechado (ein unaufgeschlossenes Reich) de trevas. (...) Enquanto a idéia contém em si o momento da determinidade perfeita, o outro conceito com o qual, nela, o conceito se relaciona tem, ao mesmo tempo, em sua subjetividade, o momento de um objeto; aqui a idéia acede, por conseguinte, à figura da consciência de si, e, segundo este lado, encontra-se com sua apresentação" (id., ibid.). Se a Idéia se encontra com a consciência de si, esta só o é por uma outra consciência de si, quer dizer, esta figura que pronuncia a sentença da unidade de si mesma como sujeito e da unidade de si mesma como objeto; daí que precise se afirmar novamente como "consciência”, o que fenomenologicamente conduz de uma figura singular concreta (o Gewissen) ao espírito absoluto desdobrado em arte, religião e filosofia. Já na instância lógica, o problema concerne, por seu turno, à necessidade de suprassumir a contradição entre verdade e liberdade do ponto de vista da idéia teórica e da idéia prática, exigindo, então, a passagem que vai da Idéia do conhecer à Idéia absoluta. 
Como Hegel diz expressamente, é a lógica especulativa que faz compreender o pormenor dessa passagem como identidade concreta (cf. Hegel 18, § 141, adendo).

Por sua vez, o caminho para a solução da antinomia dianoemática vinha expresso por uma tentativa bifronte: nova determinação da verdade e nova determinação da "missão" de cada filosofia. Esta segunda - programática, mas não epistemologicamente - deve preceder aquela, pois, caso contrário, perdese em aprofundamento do conceito de verdade filosófica, incorrendo naquilo que é denominado uma solução por mero estratagema, ou ainda solução de mero compromisso. A solução do caráter antinômico da relação entre filosofia e história implica uma nova configuração quaternária na qual o próprio dianoemático encima a instância decisiva, seguido de perto pelo ceticismo que ousasse dizer seu próprio nome, "le scepticisme déclaré”. Já a "solução de compromisso" implica um reducionismo, à medida que o sentimento do valor intrínseco das doutrinas - mera ilusão - é transmutado em valores cujo esteio não são os intrinsecamente filosóficos: na perspectiva desta taxionomia, perfilariam os reducionismos psicológicos (Gerando, Cousin), psicológicoepistemológicos (Brunschvicg reencontrado), sociológicos (A. Comte), econômicos (Marx, Lukács). Por seu turno, a "solução por estratagema” é aquela em que uma filosofia se afirma como instância máxima, enquanto as demais só seriam toleráveis na medida em que reajustadas ao nível da primeira. O estratagema, segundo Guéroult, consiste na violação “do caráter completo e autônomo das doutrinas convertendo cada uma dessas verdades totais e reciprocamente repulsivas em verdades parciais ou pontos de vista relativos que se completam e concordam na verdade superior de uma doutrina (Leibniz, Hegel); ao nelas absorver, sob forma de sistemas particulares, todo dado objetivo real e possível da história, elas detêm o curso desta” (Guéroult 8, p. 65).

Nova determinação da verdade e da missão filosóficas? A resposta é fornecida pelo caráter - duplo, é claro - da dianoemática. Graças ao recurso à positividade, ela empreende a tentativa de dar conta de fatos dados. Não será difícil adivinhar que se trata da existência de metafísicas que "encontramos já constituídas” na história, ou, por outro viés, o sentimento de valor objetivo que a todas elas o historiador atribui: não a criação de uma nova metafísica, mas tão-somente a aceitação das metafísicas que a história nos oferece; não mutilação e negação parcial ou total, mas a realidade filosófica de cada filosofia. Con- 
tudo, como vimos no caso do monógrafo rigoroso, por um lado, todas as filosofias visaram aquilo que não foram capazes de atingir (vérité de jugement, pertinente ao dogmatismo) e, por outro, atingiram aquilo que não haviam visado (veritas in re, pertinente à apreciação estética). Devido a este fato, dirá Goldschmidt, o filósofo "só guarda a consciência de sua visada: a consciência (e o saber) de seu fracasso e de seu êxito, não intencionada, é atribuída ao dianoemático” (Goldschmidt 5, p. 237). No caso do polemista convicto esgrimindo contra a crítica hegeliana, a questão fica ainda mais grave, pois o sistema hegeliano não visa a uma verdade, tal como seria o caso da verdade extrínseca da science, e, no entanto, deveria ser chamado a se contentar com a verdade intrínseca da obra de arte ${ }^{20}$. Neste caso, porém, a fábula hegeliana não viria acompanhada de nenhuma lição de moral, ou, noutros termos, as virtudes especulativas não dispõem de nenhuma lição imediata a oferecer; antes, requerem a passagem pelo conjunto de mediações que a lógica preside, principalmente quando ele se mostra configurado sob a forma do acontecimento filosófico. Fosse suficiente admitir a suspensão do valor de verdade da filosofia em favor de sua recepção estética, seria possível dizer que a história estrutural da filosofia está para a história filosófica da filosofia assim como um libreto de ópera está para a sua inteira apresentação. Aqui bastaria que fosse lembrada a seguinte proposição: "Na facilidade com que o espírito se satisfaz, pode-se medir a grandeza de sua perda” (Hegel 14, p. 25) ${ }^{21}$.

Graças ao recurso a seu caráter transcendental, a dianoemática em projeto se propõe uma tarefa cujo cumprimento seguirá uma linha pontilhada ad infinitum, destinada a permanecer incessantemente tarefa: como é possível a "experiência filosófica” presente na história? Esta questão de estirpe claramente kantiana se diferencia de Kant na medida em que o filósofo de Königsberg deixava - por duas razões - as doutrinas oferecidas pela história como que despojadas de todo valor: de fato, apoiando-se nos prefácios da Crítica da razão pura, somos levados a constatar que os adeptos da metafísica comparecem nesta arena em permanente e fundamental desacordo; de direito, basta recorrer à “Doutrina Transcendental do Método" para se aperceber de que, na passagem concernente às condições da ciência possível, a união dos conceitos com as intuições (puras ou empíricas) é uma união de que carece a destronada rainha das ciências - disto decorre que, nela, os juízos sintéticos a priori sejam ilegítimos; em contrapartida, cumpria reconhecer o valor objetivo das matemáticas 
e da física. Ora, segundo Guéroult, só é permitido a Kant lançar a pergunta como a metafísica é possível enquanto ciência? - pela razão de que, previamente à demonstração da legitimidade das ciências, o filósofo demarcou em sentidos diferentes - quer para as ciências, quer para a metafísica - a questão quid facti. Was ist Metaphysik als Wissenschaft möglich? Agora Guéroult se insurge contra Kant e seu todo definitivo “que já não pode ser mais aumentado”. Contra o fato nihil actum reputans, si quid supresset agendum (Kant 21, B XXIV), Guéroult sempre poderá responder afirmativamente à questão quid facti, o que reconduz o monógrafo a se haver com a filosofia como coisa do passado. Afinal, o que poderia ser precisamente aumentado senão o comentário, a crítica do comentário e assim por diante? Mas seriam os filósofos, tomados em seu conjunto, um imenso Aristóteles, fato dado ao lado do qual, na melhor das hipóteses, o fato dado dos comentadores seria um imenso e laico Tomás? O certo é que o dianoemático recusará um suposto protesto kantiano diante do "curso do mundo" enquanto mundo da metafísica: "Deste postulado [kantiano: o nãovalor absoluto de tudo aquilo que não possui o caráter de ciência (do mundo material)], resultam simultaneamente uma interpretação da história da filosofia e um conceito daquilo que deve ser a metafísica” (Guéroult 8, p. 68; o grifo é do autor). Com a recusa de chancelar este Sollen contido no postulado kantiano, a questão de que se ocupa o dianoemático, quid juris, pode ser enfim formulada: como é possível a metafísica enquanto tal (e não enquanto ciência), isto é, com este valor $=\mathrm{x}$ que a torna digna de estudo objetivo (digna de se tornar objeto da filosofia)? (id., ibid., p. 70). A tentativa de uma dedução da realidade dos sistemas levará Guéroult a dizer que "a idéia de uma atitude científica perante a metafísica considerada objetivamente na história, unida à idéia de uma ciência possível das condições de possibilidade da realidade das metafísicas na história, é a idéia de uma dianoemática” (id., ibid., p. 244).

Contudo, ao reservar para Hegel, quer o tratamento historiográfico, quer o polêmico, estes, na medida em que são indissociáveis dos pressupostos dianoemáticos, não ofuscariam a complexidade das relações histórico-filosóficas entre Hegel e Kant? - É o que talvez tenha percebido A. Stanguenec, ao propor, com maior amplitude, um repertório dos procedimentos críticos hegelianos: inconseqüências formais, contradições e incompletudes sintéticas são relacionadas com a estrutura compositiva das três Críticas. Sem deixar de fazer o elogio do artigo de Guéroult sobre os “deslocamentos”, o autor propõe 
uma interpretação de maior fôlego, ao assumir como tarefa, no caso específico da crítica à filosofia moral, que se adote uma perspectiva distinta: "Retomamos a análise na ótica, para nós decisiva, de uma contradição em Kant entre a Dialética e a Analítica” (Stanguenec 27, p. 221). Ponto de vista esclarecedor em mais de um aspecto, porém, apesar de reconhecer a necessidade de "renunciar às facilidades da separação transcendental”, Stanguenec não faz justiça às exigências propriamente ontológicas da filosofia hegeliana, ao englobá-las todas sob o título de uma "pré-compreensão especulativa das questões kantianas" (id., ibid., p. 345), restaurando, ao que tudo indica, uma separação dualizante de matriz transcendental. Seria o caso de nos perguntarmos, por exemplo, por que, nesse inventário e classificação quase completo das remissões hegelianas a Kant, o autor não tratou de explicitar o teor essencial daquilo que Hegel assume como o interesse supremo da razão a que já fizemos referência: "Este seu interesse", dirá Hegel, "não tem o sentido de [a razão] proceder como se ela se pusesse em princípio contra a oposição e a restrição, pois a cisão necessária é um fator da vida, que eternamente se forma pondo oposições, e a totalidade na suprema vitalidade só é possível através do [seu] restabelecimento a partir da suprema separação (Trennung). Ao contrário, a razão se põe contra a fixação absoluta da cisão pelo entendimento, e [se opõe] tanto mais, quanto os opostos absolutos brotaram eles mesmos da razão" (Hegel 20, p. 109) 22.

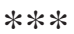

Ao se fechar a descrição da Idéia de uma dianoemática, deparamos com quatro atitudes, em princípio igualmente possíveis quanto à relação entre o valor objetivo da metafísica e o da ciência: segundo Guéroult, a primeira, humiana, negaria ambos os valores ${ }^{23}$; a segunda, kantiana, seria positiva com relação à ciência e negativa diante da metafísica; a terceira, inversão inominada da precedente, negativa com relação à ciência e positiva perante a metafísica; a quarta, gueroultiana, positiva diante de ambas. Se a terceira atitude fosse a hegeliana, assim formulada, por certo não seria a mais adequada para compreender o que afinal significa, para Guéroult, operar sua própria "inversão do hegelianismo", pois aquela atitude não apenas é desmentida pelos textos em que Hegel reabilita o entendimento ${ }^{24}$, como, de resto, as relações entre Hegel e a metafísica não 
poderiam ser resumidas a uma "atitude positiva". Em todo caso, o empenho do dianoemático está autodeterminado a seguir uma via duplamente positiva. Por um lado, deveria apaziguar, caso sua solução não levantasse outros problemas, todas as inquietudes suscitadas pelo "processo dialético": contradições, apriorismos, mecanicismos, clausura terminal da filosofia e da história; assim, só teria atingido sua meta, "ao operar a conciliação das pretensões de todos os sistemas” (Guéroult 8, p. 225). Por outro lado, cada um deles deveria valer como verdade total em sua esfera respectiva, embora esta não pudesse estar afetada por nenhuma particularidade. Mediante os corretivos inseridos na metodologia transcendental, a "viravolta gueroultiana" do hegelianismo partiria, não de um sistema demonstrado para dele deduzir a realidade da história da filosofia como conclusão, mas antes, partiria desta realidade para deduzir um sistema (id., ibid., p. 224). Que Hegel procedesse como antecipa o dianoemático, é algo que, segundo seu projeto, lhe caberia demonstrar no Parágrafo 61 de sua Philosophie de l'histoire de la philosophie, infelizmente não redigido. Mas é de se presumir que, nesta virada radicalmente idealista, o acento recairia nos bastidores doutrinais das questões de método, comprometendo de antemão a verdade total a que o sistema hegeliano teria direito em sua esfera própria, separável, visto que diferente. Nestes termos, contudo, perfazendo seu circuito de trincheiras transcendentais, uma monografia estritamente gueroultiana de Hegel seria inexeqüível, não tendo cabimento senão o aporte do historiógrafo seletivo e do polemista convicto. Tais expedientes são tanto mais instrutivos quando se recorda que a "inversão" operada em outro século por um neohegeliano não assume o significado e o alcance de uma virada "a mais", posta no horizonte de oposições abstratas. Se a descoberta da realidade do trabalho fosse apenas uma questão de reinversão da doutrina hegeliana, não haveria nem ação nem oposição diretas entre Hegel e Marx, assim como, para Guéroult, nenhuma ação direta teria Kant exercido sobre Hegel. Estando em jogo a realização efetiva da liberdade, o que nos interessa não se encontra, como se vê, na esfera em que teorias concorrentes se desenvolvem para dar conta de uma conservação intacta da história da filosofia, mas antes, na possibilidade de reconhecer antagonismos teóricos reais: decerto voltar a ler os clássicos, entretanto, não de modo incondicional. Se presentificar o potencial crítico da filosofia ainda tem algum sentido para a história da filosofia, a relação de oposição entre os autores assume, mediante a paciência na lida com estruturas comparáveis, um 
alcance que não seria meramente estranho àquilo que dizia Marx no Posfácio da segunda edição alemã de $O$ capital: "Meu método dialético não apenas difere pela base do método hegeliano, mas é sua oposição direta (ihres direktes Gegenteil)” (Marx 25, p. 555).

Minucioso na seleção de um pressentimento do problema da história da filosofia como objeto digno de uma história possível, o historiógrafo coletava, retrospectivamente, os pressentimentos da filosofia das filosofias. Para preservar a autonomia e a auto-suficiência delas, não obstante arruinadas por suas pretensões respectivas à verdade, conduzia o fato de cada filosofia autônoma através de um escoamento dianoemático, para fazê-las banhar-se nas águas do dado geral como conjunto da história da filosofia; de antemão conhecido o fato, fornecer conceito seria estratagema e fabulação; daí a constituir o dado geral, bastava o passo das verdades bipartidas, para que tal protocolo aliviasse a consciência estrutural daquilo que a contradiz e que precisava reinverter. Objetividade e verdade uma vez conduzidas à esfera dos valores, o historiador da escola objetiva, mesmo dispondo de um arsenal de perspectivas, silencia os problemas da relação entre Hegel e a filosofia transcendental, esvazia os conteúdos histórico-sociais e não atina com o porquê de Hegel silenciá-los, nos momentos em que de fato o fenomenólogo o faz. A questão neste caso não é só de vindicar que se faça justiça aos textos (o que, como se vê, não faz mal nem ao polemista estrutural), mas de saber em nome de que realismo a leitura dos clássicos seria feita.

Por sua vez, se houvesse estreiteza na “interpretação” hegeliana de Kant, seria preciso, para não escamotear suas limitações, compreender que ela tem o alcance de sua época. Nisto ainda ressoa a pretensão de ir assinalando ao falecido, soberanamente, o posto que deveria ocupar: o chamado renascimento hegeliano, iniciado com o livro de B. Croce, empenhado em desenredar o que houvesse de vivo e o que houvesse de morto em Hegel, emergiu sob o signo de tal presunção, como observou Adorno por ocasião do $125^{\circ}$ aniversário da morte de Hegel. Há muita pressa em lançar a pergunta pelo que significam Kant e Hegel para o presente, ao passo que não se lança a pergunta inversa: - que 
significa nosso presente perante Hegel? (cf. Adorno 1, p. 9). Entre o que desceu ao túmulo num cemitério alemão e o exilado no arquivo dianoemático, não há por que optar. Cumpre, simplesmente, voltar a freqüentar os textos. Mas, se houver na filosofia de Hegel partes envelhecidas, isto atesta que há posteridades reconhecíveis, inclusive, é claro, em relação às filosofias, razão a mais para revisitarmos sua filosofia da história. Dos anos 30, quando Guéroult começou e teve de interromper a redação de sua filosofia da história da filosofia, até nossos dias, as discretas ressalvas de Goldschmidt parecem confirmar o preceito de que, tratando-se de método estrutural, é melhor praticá-lo do que buscar elucubrações em separado acerca da doutrina que lhe seria subjacente. Nestes termos, a dianoemática seria menos o Diamat do estruturalismo do que os prolegômenos a toda história da filosofia que quisesse se apresentar como filosofia.

Por seu caráter positivo, no interior da dianoemática, toda filosofia visava o que não atingia e atingia o que não visava, ao passo que o filósofo da história da filosofia se manifestava como o guardião da consciência, quer referida ao fracasso (não tencionado), quer referido ao êxito (não tencionado tampouco) de cada filosofia. Por seu caráter transcendental, o projeto dianoemático se propunha uma tarefa infinitamente prorrogada, destinada a permanecer tarefa e multiplicando seus afazeres pela autodelegação de funções, na relação de parceria consigo mesmo em que, seguindo as pegadas de Kant, Guéroult se tornou gueroultiano. A dianoemática permaneceria sendo a filosofia das filosofias na ordem das razões, enquanto o estruturalista permanecesse como o polemista convicto na ordem do dia; só que esse dia era o que prefaciava os embates ideológicos entre os defensores da estrutura e os partidários da história - idos de 50.

Ao enfatizar os efeitos nocivos da crítica hegeliana - filósofos travestidos em hommes de paille -, Guéroult procurava mostrar que inconscientemente Hegel substituíra, ao verdadeiro Kant, algum tipo de fantasma ${ }^{25}$. Mas importar as noções reducionistas do historiógrafo e do dianoemático, para generalizá-las no horizonte da recontextualização da crítica hegeliana, é tornar esta última, como tal, ou irreconhecível enquanto constitutiva da filosofia hegeliana, ou desclassificável enquanto obra anacronizada de historiador. Dessa operação, o "recontextualizado" sepulta a contradição e convive com o pseudônimo de um outro fantasma: "Pai da história moderna da filosofia”. 
Para nós, não se tratava de dizer que Hegel deveria se mostrar imune a toda crítica, mas de ir procurando entender que tendências teóricas atravessam o Hegel que é objeto dessa crítica da crítica hegeliana. Ao se encaminhar de modo abstrato pela via enciclopédica e ético-jurídica, sua recontextualização relegou ao silêncio, em primeiro lugar, o contexto próprio do itinerário fenomenológico: nenhuma palavra sobre o que precede a moralidade, remissão sem mediações, de antemão desqualificadas, ao espírito absoluto. Porque a exposição analítica redunda num vácuo histórico e social da formação do sistema, a desconexão das esferas do espírito é o preço a pagar pelo abandono da lógica. A contradição das filosofias - sempre entrevista, jamais assumida erigiu obstáculos intransponíveis para o espírito lógico de feitio gueroultiano, pronto que estava para evitar a todo custo a ruína das filosofias passadas; se com isto recusava o próprio ponto de partida da filosofia hegeliana, ao mesmo tempo a contradição entre as filosofias não era reconhecida senão para ser ignorada, ou o que é pior, objeto de gommage. Por isso mesmo, em seu artigo, passou sob silêncio o alcance do espírito lógico propriamente hegeliano, assim como, de resto, o ponto de partida da temporalidade histórica cujas determinações conceituais têm início, precisamente, com uma meditação sobre as ruínas. Pelo julgamento de apriorismo, Hegel, finalmente rendido ao plano dos fatos, teria sido o escritor de uma ciência da lógica tão estranha quanto mutilada: nunca teria ido além do Parágrafo 199 da Enciclopédia, nunca teria criticado o objeto e o processo mecânico na Lógica subjetiva ou doutrina do conceito. É que Guéroult supunha desde o início aquilo mesmo que estava em questão, a saber, o não-valor de verdade como vérité de jugement era declinado a toda filosofia, a fortiori, como se a verdadeira realidade fosse o privilégio da dianoemática; direito diferencial que a ele não nos cabe negar, pois ele já se fez valer pelo ethos acadêmico em que o autor se insere. Por seu turno, a concessão gueroultiana de direitos à genialidade de Hegel corresponde, de modo complementar, à instauração de interditos fundamentais: nem verdade de julgamento, nem verdade intrínseca, muito menos, verdadeira realidade. Por este viés, a filosofia de Hegel como philosophie toute faite aparece como um resultado abstraído do processo que a ele conduziu, as objeções de Hegel, fundamentais a este respeito, seriam meras alegações, inaudíveis lá nas altitudes em que o dianoemático se outorga os direitos de supremo juiz das pretensões da história da filosofia. Feita em nome de um anti-reducionismo, a crítica da crítica se 
mostra problemática, não só porque a Wissenschaft hegeliana não é pura e simplesmente um reducionismo, mas porque a apreciação gueroultiana não é estranha ao reducionismo. Porque a recontextualização gueroultiana é um antireducionismo de Kant, é um reducionismo de Hegel; mais precisamente, a coerência integral do ponto de vista (corrigido) do kantismo oferece a revelação epigônica da prática rigorosa ao metamorfosear Hegel em plantador de espantalhos. Para mostrar que, por sob a crítica hegeliana, está sempre - de modo deformador - um falsificador sistemático, Guéroult se viu obrigado a incorrer em procedimentos que abominava. O benefício correlato a este custo seria a condenação da possibilidade de uma história da filosofia (potencial) diversa e diretamente oposta àquela (não menos potencial) que pôde ser sugerida pela correção da apreciação kantiana das metafísicas passadas. Assim como o polemista convicto é chamado a tomar a palavra quando o monógrafo deve silenciar, assim também os interesses da razão hegeliana seriam incompatíveis com os interesses do dianoemático: os primeiros começariam a vigorar a partir do momento - lógico - em que os segundos já não podem mais avançar.

Para terminar esta parte de nosso estudo sobre M. Guéroult como crítico da crítica hegeliana, assinalemos que a motivação desta última é eminentemente filosófica. Trata-se de examinar - à luz dos enraizamentos fenomenológicos, do ancoramento lógico-dialético e especulativo, dos desdobramentos ético-jurídicos, à luz do tribunal da história e da história da filosofia - em que medida a filosofia moral kantiana contribui para a efetiva realização da liberdade. Sem este reconhecimento do direito absoluto da filosofia à verdade, sem a admissão dessa liberdade, para que um filósofo no início dos oitocentos faria uma investigação crítica da filosofia prática kantiana? A título de comparação, bastará meditar com mais vagar sobre o papel de Kant na constituição da filosofia hegeliana e será possível antever, sob o solo aparentemente homogêneo das pretensões dianoemáticas, uma defectibilidade profunda, pois não permite apreender que - junto a remanejamentos conceituais, prolongamentos temáticos, pontos de ruptura irreversíveis - uma redisposição arquitetônica encontrava um arremate que não ficaria sem conseqüências. Se assim se abandona um certo campo de tensões entre Sollen e Sein, onde via de regra as contradições objetivas são traduzidas em conflitos de ordem moral, é para reencontrar novas tensões noutro campo da filosofia prática; é porque as disposições ético-racionais estariam enraizadas, em última instância, numa lógica de matriz ontológica em 
que, renunciando às facilidades da separação de cunho transcendental, liberdade e verdade não estariam destinadas a permanecer infinitamente cindidas. É neste sentido que aqui nos permitimos retomar a indagação de Rubens Rodrigues Torres Filho: o pensamento hegeliano, se tomado em todo o rigor que comporta, não seria vigoroso o bastante para superar o seu próprio descobridor? (Torres 28, p. 142).

\begin{abstract}
We discuss in which sense it is possible to analyse the limitations of the structural reading applied to the Hegelian philosophy, namely when the latter criticizes Kant's morality. Based on an article written by M. Guéroult about this subject, we compare on the one side his assumptions, mainly in the dianoématique, on the other side the theorethical and practical requests which guide the consequences of this critique.
\end{abstract}

Key-words: critique - system - morality - displacements - structural method and doctrine

\title{
Notas
}

1. A bibliografia sobre o problema é vasta. Para uma visão geral, pode-se consultar K. Steinhauer (Hegel Bibliographie. Materialen zur Geschichte der internationalen Hegel-Rezeption und zur Philosophie-Geschichte, Munique/Nova York/Londres/Paris, K.G. Saur, 1980). Outra referência parte do Congresso da Internationale Hegel Vereinigung, de 1981, em Stuttgart, cujo tema histórico (dentre outros) girou em torno do problema da "fundamentação em filosofia", principalmente da relação entre filosofia transcendental e filosofia especulativa: Kant oder Hegel? Über Formen der Begründung in der Philosophie (org. Dieter Heinrich. Stuttgart, Klett-Cotta, 1983). Em um obra de F. Menegoni (Moralità e morale in Hegel. Pádua, Livraria Editrice, 1982), sobretudo na "Introdução", é possível encontrar um tratamento das diferentes tomadas de posição concernentes a este campo de estudos hegelianos (Spaventa, Riedl, Ritter, Falley, Lukács, Peperzak, Reboul, Valentini, D’albiero, Heimosoeth, Weil e outros). Os limites do presente texto não permitem entrar na bibliografia mais recente sobre o problema. 
2. Este artigo (Guéroult 7) foi publicado igualmente na coleção Studien und Materialen zur Geschichte der Philosophie (ed. cit. nas ref. bibl.), sob o título "La critique hégélienne de la morale kantienne”. Uma possível pista para a mudança de título efetuada por Guéroult, quando da edição alemã, seria o caráter problemático de se admitir a existência, para Hegel, de uma noção tal como a de "consciência moral".

3. A motivação de pôr um instrumento sólido e adequado no lugar dos estudos genéticos, que, na França, “causaram tantas decepções”, fornece a V. Goldschmidt o ponto de fuga para esboçar o quadro de uma breve história do estruturalismo. Oposição esclarecedora, segundo ele, pois antecipou, em 1950, "les affrontements idéologiques" que mais tarde deveriam se produzir entre os partenaires de l'histoire e os tenants de la structure: "Durante muito tempo, aquela disciplina [a do método genético] acreditou fazer progressos decisivos e se constituir como ciência digna deste nome, ao trabalhar sob o signo da evolução. Ao fazê-lo, sofria a influência oculta de um hegelianismo vulgarizado e laicizado e, de modo mais consciente, a atração do positivismo comtista (e também spenceriano), assim como o prestígio dos gostos biológicos da época” (Goldschmidt 6, p. 240).

4. Cf., por exemplo, os estudos sobre Dilthey (Revista Brasileira de Filosofia, 1952), Bréhier (Revista Brasileira de Filosofia, 1954; e também Revue de Métaphysique et Morale, 1952), E. Souriau (Mélanges d'esthétique et de science de l'art, Nizet, 1952), Brunschvicg (Bulletin de la Société Française de Philosophie, 1954), Bergson (Etudes Bergsonniennes, V, 1960) e Renouvier (Revue de Théologie et de Philosophie, 1967).

5. Cf. também Guéroult 7, p. 48.

6. Guéroult admite o dualismo entre a moralidade e a realidade efetiva como essencial para a doutrina kantiana, enquanto o contraponto entre Moralität e Sittlichkeit desempenha o papel de elucidação por contraste. Tal admissão tem o mérito, em nada pequeno, de reconhecer, ainda que formalmente, o situs a partir do qual se desenvolve a crítica hegeliana. Acresce que, no registro fenomenológico, por exemplo, se a Wirklichkeit é constitutiva daquela coincidência omniabrangente do espírito com a verdade, é porque o espírito - reiteradamente posto à prova em seu desenvolvimento processual e com vistas a se tornar consciente de si mesmo como espírito - elevou-se, para empregar o vocabulário da representação, a um ponto de vista privilegiado a partir de onde exerce seu droit de regard. Como tal, em suas últimas instâncias, pode aparecer como dotado de uma autoridade quase incomensurável e próxima da liberdade absoluta, já criticada no caso do terror jacobino; porém, como o espírito é patologicamente amnésico, é apenas graças ao jogo de recapitulação de seus momentos que aquela totalidade espiritual acumula- 
da é reencontrada, não mais apenas sob seu aspecto fenomenológico, mas como presente nessa consciência que o espírito, por fim, adquire essencialmente de si mesmo. Trata-se, pois, de um jogo de assunção e de elevação em que o espírito se subtrai à sua própria imediatez, furta-se a si mesmo como fenômeno do espírito. É essa subtração efetuada pela essência espiritual, mas subtração à sua própria imediatez, que constitui o descenso do espírito à sua própria forma tripartite; como para Hegel é essencial que o espírito acompanhe o andamento da forma, vale a pena insistir: "O espírito desce de sua universalidade, através da determinação, até a singularidade” (Hegel 15, p. 146).

Aqui é possível ao menos, para não simplificar mais que o necessário, indicar o lugar da realidade efetiva propriamente dita. A totalidade do espírito só é realidade efetiva enquanto organização singular da experiência: resta, desta subtração, que a realidade efetiva não se encontra nos momentos determinados (consciência, consciência de si, razão e espírito, segundo seu reagrupamento ternário). Por um lado, quanto ao lugar: apenas enquanto compenetrada pela individualidade é que a realidade se torna realidade efetiva (idem 14, p. 247). Por outro, quanto a seu alcance: apenas enquanto figura singular concreta é que experimenta por si mesma sua liberdade absoluta (id., ibid., p. 94); é que, para essa individualidade, toda realidade efetiva se mostra como espiritual. Portanto, primeiro, se a realidade efetiva estiver compenetrada pela figura singular concreta, segundo, se esta se experimenta como absolutamente livre - e é justamente isto que toda a Fenomenologia pretendia ter demonstrado -, então será possível dizer que, em primeiro lugar, o espírito "possui a forma da pura liberdade perante o Outro forma que se exprime como tempo" (idem 15, p. 146), tempo que, segundo a célebre proposição da Enciclopédia, é o ser-aí (Dasein) do conceito; em segundo lugar, cada um dos momentos particulares, porque são apenas momentos, porque não estão providos de ser-aí, Dasein, diferente dos outros momentos, não têm tampouco nenhuma existência temporal. Eis o que vai tornar possível a reconciliação, no nível fenomenológico, entre Bewusstsein e Selbstbewusstsein.

7. Claro que, no caso, não teria cabimento opor, a uma "philosophie des philosophies", outra que se presumisse tal, não tanto porque esse delírio poderia encontrar um lugar, quer muito preciso, tal como nas estações por que passa a consciência na Fenomenologia do espírito (cf., p. ex.,"A lei do coração e o delírio da presunção”, Hegel 14, p. 231 e ss.), quer demasiado incômodo, como nas instituições destinadas a receber cópias vivas de mais um Napoleão. Em contrapartida, o que talvez cause incômodo é o tipo de "heroísmo grego" que, em tempos mais prosaicos, Guéroult parece ter por vezes encarnado e a que, em nome do bom senso, Goldschmidt houve por bem apor, no final do artigo supra, uma discreta e

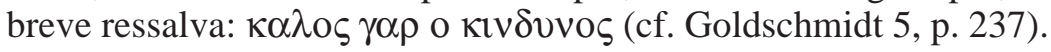


8. Para a comparação entre tais partições e aquelas operadas por V. Goldschmidt e G.-G. Granger, cf. Arantes 2, sobretudo p. 123-35.

9. Neste artigo, Guéroult concede a Hegel um tratamento diferencial: ao comparar a primeira concepção hegeliana de história da filosofia (onde predomina a idéia de totalidade orgânica, via a estética de Schelling) com a segunda (tal como se desenvolve a partir da Fenomenologia), o historiógrafo conclui que, entre ambas, não há contraste absoluto, mas deslizamento (glissement) de uma a outra.

10. Trata-se da nota 68 da edição francesa da Fenomenologia do espírito (Paris, Aubier, 1941, p. 35).

11. "No que concerne às verdades históricas - para mencioná-las brevemente enquanto consideradas do ponto de vista exclusivamente histórico, admite-se sem dificuldade que dizem respeito ao ser-aí singular, a um conteúdo sob o aspecto de sua contingência e de seu arbitrário; - determinações do conteúdo que não são necessárias. Mas até mesmo as verdades nuas, como as supracitadas em exemplo [quando nasceu César? quanto mede o estádio?], não são sem o movimento da consciência de si. É preciso muito comparar para conhecer uma só delas; há que consultar livros ou pesquisar, seja de que maneira for. Ainda no caso de uma intuição imediata, só terá tido como possuindo verdadeiro valor seu conhecimento junto com suas razões; embora o que realmente interesse seja o resultado puro e simples” (Hegel 14, §41). Os parágrafos seguintes tratam de uma articulação peculiar pela distinção de natureza entre verdades científico-positivas e filosóficas.

12. Devemos a expressão a Paulo Eduardo Arantes.

13. Tivemos acesso ao manuscrito deste curso graças à gentileza do professor. Aqui não cabe restituir o pano de fundo em que se insere o debate de Bento Prado Jr.. A Revista de Estudantes de Filosofia (Departamento de Filosofia da FFLCHUSP) prevê publicação deste texto para o seu segundo número.

14. Cf. verbete correspondente no Deutsches Wörterbuch, de Jacob e Wilhelm Grimm (Munique, dtv, 1984, vol. 25, p. 1736-1739).

15. Os grifos são do autor.

16. Em seu Hegel - a ordem do tempo (cf. Arantes 3), Paulo Eduardo Arantes apresenta uma reconstituição histórica que vai “desde a retomada da questão da espacio-temporalidade a partir da filosofia pós-kantiana, até a compreensão do tempo como 'grau zero do Conceito', mas dialeticamente redobrada e circunscrita por este último (em 'O tempo e seu duplo')” (Torres 28, p. 139). Comentando esta abordagem de Hegel como pós-kantiano, G. Lebrun assinala: "Sempre nos recordam que, se o sistema especulativo é uma demolição da Crítica kantiana, é tam- 
bém um trabalho que se efetua a partir dela e com ela. E Paulo Arantes mostranos, até, que a originalidade de Hegel melhor aparece em vista das opções kantianas que ele rejeita” (Lebrun 22, p. 25).

17. Não será inoportuno registrar que foi G. Lukács o primeiro a notar esta diferença (Cf. Lukács 23, p. 277 e ss.). Que se recordem os capítulos nos quais Hegel descreve a observação da individualidade humana, a razão ativa no individualismo moderno, assim como as obras humanas e a dialética da ação, sobretudo na terceira parte da Fenomenologia.

18. Vale aqui ressaltar que, na última parte da Ciência da lógica (lógica subjetiva ou doutrina do conceito), o problema do começo (Anfang) é contraposto ao ponto de partida (Ausgangspunkt) entendido enquanto princípio natural. Este é precisamente o começo de que se parte no desenvolvimento da história (die Historie) de um indivíduo que se cultiva: neste caso, trata-se menos da Verdade e mais da história narrativa do indivíduo no âmbito da representação e do pensamento fenomênico (isto é, narração dos sentimentos, intuições, das vivências ainda em via de serem organizadas enquanto experiência). Ora, diz Hegel acerca do conceito em geral (Hegel 17, p. 53-54), a Filosofia não deve ser narração, mas conhecimento daquilo que, no interior da narração, é verdade; numa palavra, Filosofia é conhecimento conceitual. Portanto, há pelo menos um pressuposto para o ponto de partida da Wissenschaft: o próprio conceito de saber (id., ibid., p. 39-40): “A ciência donde resulta esse saber é a Fenomenologia do espírito, que começa com a consciência imediata”; assim, neste caso, o começo é a determinação de uma figura singular concreta, determinada portanto como consciência de algo e como consciência imediata.

A certa altura do capítulo cuja figura singular é a do Gewissen, por exemplo, saber e realidade efetiva serão relacionados de tal modo, que parecerão se identificar: com efeito, neste capítulo, o problema do começo como ponto de partida natural poderá aparecer formulado como o problema da imediatez da consciência que o espírito tem de si mesmo; enquanto permanecer temporalmente como figura singular concreta, sua realidade efetiva ainda terá como tarefa operar a reconciliação entre por um lado a história narrativa permeada de contingência e por outro lado o conceito necessário - ou seja, restará operar a reconciliação em que sua própria história vale como história conceituada (concebida e concipiente), reunificando, portanto, certeza e verdade, a certeza por excelência do espírito e uma coletividade efetivamente viva.

19. Hegel remete aqui às páginas 549 e seguintes da primeira edição de 1807. Trata-se, com efeito, do capítulo acerca das discordâncias entre a visada moral e sua tradução em realidade efetiva. 
20. Haym foi o primeiro a sugerir que a Fenomenologia do espírito fosse lida como uma obra de arte: Hegel teria sido, neste caso, o autor de uma Divina comédia. No primeiro capítulo de Genèse et structure de la Phénoménologie de l'Esprit, Jean Hyppolite compara a obra de 1807 com romances de formação, sobretudo o Emílio, Os anos de aprendizado de Wilhelm Meister e Heinrich von Ofterdingen; porém, ainda que se adotasse a perspectiva de uma recepção estética, seria preciso dizer com Hyppolite que se trata de um romance filosófico de formação.

21. Neste passo seguimos a tradução francesa de J. Hyppolite (ed. cit., p. 11).

22. Citamos a partir da tradução de Marcos L. Muller ("Introdução" das Linhas fundamentais da filosofia do direito. In: Analítica; vol. 1, nº 2, 1994, p. 158-159, nota 14).

23. Acerca de uma dimensão positiva entre o ceticismo e a concepção empirista da ciência moderna, "desmentindo o juízo completamente negativo do primeiro", cf. o artigo de Roberto Bolzani Filho (Bolzani 4, sobretudo p. 61).

24. Seria possível citar grande número de passagens; por ora, bastará remeter ao “conceito preliminar" da Enciclopédia (Hegel 19, notadamente o § 79) ou ao Prefácio da Fenomenologia do espírito (idem 14, p. 36 e ss.).

25. Cf. Prefácio de Etudes de philosophie allemande, ed. cit., p. 1.

\section{Referências Bibliográficas}

1. ADORNO, T.W., Trois études sur Hegel. Trad. E. Blondel e outros. Paris, Payot, 1979.

2. ARANTES, P.E., Um departamento francês de ultramar - estudos sobre a formação da cultura filosófica uspiana. São Paulo, Paz e Terra, 1994.

3. _. Hegel - a ordem do tempo. São Paulo, Polis, 1981.

4. BOLZANI Fo, R., “Ceticismo e empirismo”. In: Discurso. São Paulo, 1990, $\mathrm{n}^{\circ} 18$. 
5. GOLDSCHMIDT, V., “La dianoématique”. In: Ecrits - études de philosophie moderne. Paris, Vrin, 1984, t. II.

6.___ "Remarques sur la méthode structurale en histoire de la philosophie". In: Ecrits - études de philosophie moderne. Paris, Vrin, 1984, t. II.

7 GUÉROULT, M., “Les déplacements de la conscience morale kantienne selon Hegel”. In: Hommage à Jean Hyppolite. Paris, P.U.F., 1971.

8. _. Philosophie de l'histoire de la philosophie. Paris, Aubier, 1979.

9. _. Cours d'historiographie. Texto datilografado, disponível na Biblioteca do Departamento de Filosofia da FFLCH - USP.

10. ___ .Le problème de la légitimité de l’histoire de la philosophie”. In: La philosophie et l'histoire de la philosophie. Roma/Paris, 1956.

11. __ . "Le jugement de Hegel sur l'antithétique de la raison pure”. In: Etudes de philosophie allemande. Hildesheim/Nova York, Georg Olms, 1977 (Col. Studien und Materialen zur Geschichte der Philosophie).

12.___ "La première conception hégélienne de l’histoire de la philosophie". In: Etudes de philosophie allemande. Hildesheim/Nova York, Georg Olms, 1977 (Col. Studien und Materialen zur Geschichte der Philosophie).

13. HAYM, R., Hegel und seine Zeit. Hildesheim/Nova York, Georg Olms, 1962.

14. HEGEL, G.W.F., Fenomenologia do espírito. Trad. P. Meneses. Rio de Janeiro, Vozes, 1992, Parte I.

15. F_ Fenomenologia do espírito. Trad. P. Meneses. Rio de Janeiro, Vozes, 1992, Parte II.

16. __ Science de la logique. Trad. P.-J. Labarrière e G.W. Jarczyk. Paris, Aubier, 1972, vol. I.

17. __ Science de la logique. Trad. P.-J. Labarrière e G.W. Jarczyk. Paris, Aubier, 1981, vol. III. 
18. Principes de la philosophie du droit. Trad. R. Dérathé. Paris, Vrin, 1982.

19. Enciclopédia das ciências filosóficas. Trad. P. Meneses. São Paulo, Loyola, 1995, vols. I e III.

20. __ La différence entre les systèmes philosophiques de Fichte et de Schelling. Trad. B. Gilson. Paris, Vrin, 1986.

21. KANT, I., Crítica da razão pura e outros textos selecionados. Trad. V. Rohden e outros. São Paulo, Abril, 1985 (Col. Os Pensadores).

22. LEBRUN, G., "Hegel e a neutralização do tempo". In: Passeios ao léu. São Paulo, Brasiliense, 1983.

23. LUKÁCS, G., Le jeune Hegel. Trad. G. Haarscher e R. Legros. Paris, Gallimard, 1981.

24. MARCUSE, H., Razão e revolução. Trad. M. Barroso. Rio de Janeiro, Paz e Terra, 1978.

25. MARX, K., Le capital. In: Oeuvres. Trad. J. Roy, revista por M. Rubel. Paris, Gallimard, 1965, vol. I.

26. PORCHAT, O., "Prefácio introdutório”. In: GOLDSCHMIDT, V., A religião de Platão. São Paulo, Difel, 1963.

27. STANGUENEC, A., Hegel, critique de Kant. Paris, P.U.F., 1985.

28. TORRES Fº, R.R., “O tempo do conceito”. In: Discurso. São Paulo, 1974, $n^{\circ} 5$. 